\title{
Spirituality as a Source for the Prevention of Burnout Syndrome ${ }^{1}$ Nicole Emrová
}

\section{Introduction}

The article introduces spirituality as one of the factors that can help prevent the occurrence of burnout syndrome, specifically with social workers and workers in social services. The basic thesis of the article (namely that spirituality plays a role in the prevention of burnout syndrome) is based on the concept of man as a physical, psychological, social, and spiritual being, and also on the recognition of religiosity as an anthropological constant given to each person. The article defines burnout as a negative and undesirable phenomenon that threatens a large number of workers in the helping professions both professionally and personally. It uses knowledge of Czech sociology of religion and approaches a somewhat ambiguous and unclear domain of spirituality, religiosity and religion. Part of the article is the interpretation of the results of a quantitative research probe which examined (using questionnaires) the views of social workers and social service workers on spirituality, their experience with burnout syndrome, and the involvement of spirituality in the prevention and resolution of negative manifestations associated with burnout syndrome.

\section{An Introduction to the Discourse of Spirituality in Social Work}

In recent years, the need for the reflection of spirituality and its involvement in social work has also (gradually) been taken into account in the Czech environment. The spiritual perspective of social work in Europe, the Czech Republic and Slovakia has a long tradition of social services and social facilities. Those services and facilities and their function have been (since the beginning to the present day) influenced by Biblical-Christian spiritual inspiration. ${ }^{2}$ In some areas (for example, while working with terminally ill patients in hospice care or the elderly) it is common practice to meet the spiritual dimension and the spiritual needs of the person (the client) in practice. In other areas, however, this issue is not addressed, or only in individual cases. It is neither the aim nor the ambition of this article to further analyse the different approaches of the individual fields of social work towards spirituality. It is, however, possible that the involvement or non-involvement of spirituality in the helping process areas (so far) is related to a specific target group of social work. There are certain characteristics which make spirituality more relevant (for example, age, a crisis situation offering an opportunity for reflecting upon life values and meaning, etc.).

1 The writing of this article was supported by Grant Agency GAJU (grant no. 157/2016/H), University of South Bohemia.

2 Cf. Heinrich POMPEY - Jakub DOLEŽEL - Pavel BAJER, Editorial, Sociální práce / Sociálna práca 4/2008, pp. 1-2. 
Hamplová and Reháková in their sociological study (Czech religiosity at the beginning of the 3rd millennium) state that the elderly more often express and admit their religious beliefs. ${ }^{3}$

Social work has been evolving in the Euro-American area as an independent field for a relatively short time - its beginnings can be dated to the end of the 19th century. However, its roots extend far into history. Their integral parts were ideas based on contemporary philosophical trends, the Judaeo-Christian worldview, and theoretical models emerging from other disciplines (and later from their own theoretical backgrounds). In 2004, a new international code of ethics was adopted, defining social work as a profession promoting social change, addressing human rights issues, and empowering and liberating people in order to improve wellbeing. It interferes with areas where there is interaction between people and their environment, and it uses human behavioural and social systems theory. The basis of social work is the principles of human rights and social justice. ${ }^{4}$ One of the main tasks of social work is (according to Global Qualification Standards) education in social work (issued by IFSW ${ }^{5}$ and IASSW ${ }^{6}$ ), knowledge of human behaviour, and the development of the social environment (with special regard to the person-in-environment situation), life cycle and interaction among biological, and psychological, socio-structural, economic, political, cultural and spiritual factors (in terms of human development and behaviour). It includes also a necessary knowledge of how traditions, culture, belief, and religion influence human functioning and development at all levels, including those that can determine the sources and obstacles of growth and development. ${ }^{7}$ In these calls for social work, the spiritual dimension (which plays an important role in the lives of people who become clients of social work) is also taken into account. It is important that both the social worker and every helping professional perceive and take into consideration man as a person with all the elements of the personality, and support him or her. That means not only in the direction towards the person-client, but also in the direction towards him or herself.

In the historical development of social work, we can find different stages of involvement or displacement of the concept of spirituality or religion from this sphere. Its position in social work is still somewhat problematic. In my opinion, it is necessary to be aware of the difference between the situation and contexts in the Czech environment and those prevailing abroad. At the same time, it is to be constantly aware of the essence of social work as defined according to the International Code of Ethics, which is common to all countries and has a transnational character. Social work deals with man and his or her social environment. It is necessary then to take into account the situation, development, and specifics of the society in which the social work is performed (in connection and interconnection with the social policy of a specific state).

In order to outline the discourse of spirituality in social work, I will briefly mention some Czech and foreign authors who deal with the topic, the topics presented in the professional journal Sociální práce / Sociálna práca (Social Work), and also the proceedings of the international scientific conference named Hradecké dny sociální práce (Days of Social Work in Hradec). I am aware of the fact that there are other Czech and foreign authors, literature and research projects devoted to spirituality in social work. I have focused on the general level of this topic. Foreign literature ${ }^{8}$ commonly speaks

Cf. Dana HAMPLOVÁ - Blanka ŘEHÁKOVÁ, Česká religiozita na počátku 3. tisíciletí, Praha: Sociologický ústav AV ČR, 2009 , p. 34.

Cf. Mirka NEČASOVÁ, Mezinárodní etický kodex sociální práce - principy, Sociální práce / Sociálna práca 4/2004, p. 32.

Note: International Federation of Social Workers.

Note: International Association of Schools of Social Work.

Cf. Stanislava ŠEVČÍKOVÁ, Mezinárodní a český kontext Globálních kvalifikačních standardů vzdělávání v sociální práci vydaných IFSW a IASSW, Sociální práce / Sociálna práca 4/2007, p. 52.

8 Especially: Edward R. CANDA - Leola Dyrud FURMAN, Spiritual Diversity in Social Work Practice: The Heart of Helping; David R. HODGE, Spiritual Assessment: Handbook for Helping Professionals; Kenneth I. PARGAMENT, Spiritually Integrated Psychotherapy: Understanding and Addressing the Sacred; and others. 
about the involvement of spirituality in social work, spiritually sensitive social work and the social worker, and the spiritual needs of clients and the assessment of these needs.

The discourse of spirituality is heavily influenced by the cultural, historical and religious context of Czech society. This has included Christian-oriented spirituality, Christian social work, Christian-motivated social work, values that are (to a certain extent) shared by Christianity and social work (for example, dignity of human life, respect for each individual, a non-judgmental attitude), the usage but also the risks that faith can bring to social workers, the mutual inspiration of theology and social work.

One issue of the Czech magazine dealing with social issues ${ }^{9}$ was devoted to the spiritual dimension of social work, especially in terms of Christian spirituality. This issue presented a view which considers the spiritual support of man as a necessary part of material, physical, psychological and social help. It was based on practical knowledge about the spiritual dimension which is believed to raise different responses not only on the individual level. The issue presented a number of interesting articles that refer to the discourse of spirituality in social work - they mentioned some specific organisations that are more or less explicitly linked to the concept of (Christian) spirituality in the Czech Republic (Caritas, Diaconia, Maltese Aid etc.) Another topic of this issue was also Christian-oriented social work, ${ }^{10}$ which is based on the foundations connected to religion (Catholic Christianity). It also mentions the personal, individual beliefs of the social worker and their influence on the helping process in the Church organisation. In this context, it has turned out that faith can be an advanced competence of the social worker, but (at the same time) it is definitely not possible to assume that there are only faithful workers in the Church organisation. ${ }^{11}$ Another topic of the discourse is the Christian social work dealt with by Doležel. He is interested in the biblical roots of social work, ${ }^{12}$ biblical inspiration for social work, ${ }^{13}$ and in parishes as the places of the Church's social work. ${ }^{14} \mathrm{He}$ focuses on the spheres of spirituality, or religiosity, which are (also historically) typical of the Czech environment. In recent years, emphasis has also been placed on spirituality as such, without any reference to a particular religion. Jan Kaňák is interested in this type of spirituality in social work. He has identified a certain process of returning spirituality to social work ${ }^{15}$ and deals with the relationship of spirituality and professionalism in social work. ${ }^{16}$ The need to integrate spirituality into the curriculum of social work was dealt with by Kubicová. ${ }^{17}$ According to her, a skilled social worker is expected to have wide professional readiness in areas that may affect the spiritual plane, and the meaning of life and human existence as well. $\mathrm{CSWE}^{18}$ (the US institution engaged in the field of social work education) has issued

9 Duchovní dimenze sociální práce, Sociální práce / Sociálna práca 4/2008.

10 Cf. Alois KŘIŠŤAN - Libor MUSIL, Nezodpovězená otázka vztahu „pozorného srdce“ a „odbornosti“ v křestansky zakotvené praxi sociální práce, Sociální práce / Sociálna práca 4/2008, pp. 93-99.

11 Cf. Michal OPATRNÝ, K čemu může být sociálnímu pracovníkovi jeho víra?, Sociální práce / Sociálna práca 4/2008, pp. 85-92.

12 Cf. Jakub DOLEŽEL, Biblické kořeny sociální práce, in: Praktická teologie pro sociální pracovníky, eds. Michael MARTINEK et al., Praha: Jabok, 2010, pp. 26-39.

13 Cf. ( ) Jakub DOLEŽEL, Biblické inspirace sociální práce - a jak je nacházet? (online), in: Krestanské východiská sociálnej práce a jej misijný rozmer, ed. Štefan ŠAK, pp. 76-81, at: https://www.pulib.sk/web/kniznica/elpub/dokument/Sak3, cited 3rd June 2017.

14 Cf. Jakub DOLEŽEL, Farnost jako místo sociální práce církve. Novozákonní východiska a př́klady dobré praxe, in: Spravedlnost a služba II. Sborník odborných př́spěvků a studijních textů CARITAS-VOŠ sociální Olomouc, ed. Jakub DOLEŽEL, Olomouc: CARITAS-VOŠ sociální Olomouc, 2007, pp. 43-56.

15 Cf. Jan KAŇÁK, Postavení diskursu spirituality v sociální práci, Sociální práce / Sociálna práca 4/2015, pp. 30-46.

16 Cf. Jan KAŇÁK, Nedefinovaná profesionalita: Vztah diskursů spirituality a profesionality v sociální práci v soudobé odborné literatuře, Sociální práce / Sociálna práca 5/2016, pp. 72-91.

17 Cf. Alina KUBICOVÁ, Fenomén spirituality a jeho integrace do osnov sociální práce, in: Rizika sociální práce, eds. Martin SMUTEK Friedrich W. SIEBEL - Zuzana TRUHLÁŘOVÁ, Hradec Králové: Gaudeamus, 2010, pp. 459-464.

18 Note: Council on Social Work Education. This is the national association representing the education of social workers in the United States. It includes more than 800 accredited bachelor and masters programmes in social work. 
a recommendation saying that social work should be enriched with religious and spiritual themes. Kubicová also states that comparisons of empirical studies about religiosity and spirituality are very problematic, if not impossible. In the Hradecké dny sociální práce proceedings, Kaňák published the results of a pilot study, in which he identified the attitudes of social work students towards spirituality and religion. ${ }^{19}$ He emphasised the need for a spiritually sensible education of students. His pilot research suggested that it would be more appropriate to open spiritual themes rather than directly religious ones (especially in situations where the meaning of life and transcendency have played a role in the client's situation). Social work should not lose sight of its multidisciplinary nature in the process of engaging in spirituality, as it is necessary to use the knowledge of other disciplines such as sociology (religion), psychology, ethics, pedagogy, religious studies, theology and others.

\section{Spirituality}

To define the concept of spirituality is, as with many other theoretical concepts, very difficult. Upon closer examination, we find overlaps and blurred boundaries at least when talking about the notions of religion and religiosity. In addition, it is also necessary to take into account the lenses of the discipline through which spirituality is perceived - theology, psychology, philosophy, sociology of religion, and so forth. For the purpose of this article, I will clarify how I understand the key concepts of spirituality, religiosity and religion. With regard to the complexity of these terms, I am aware of the ambiguity and heterogeneity of understanding across the different discourses. It is not possible to capture all the circumstances relating to these concepts.

Religion can be defined by categories such as relation to the sacraments, participation in rituals, the existence of social groups, a set of ideas about the world, the existence of social norms, commands for action, and others. ${ }^{20}$ In accordance with sociology of religion, the notion of religion can be understood as a system of teachings, beliefs, practices that are connected with the sacred, and as such they have a certain social dimension. ${ }^{21}$ Contemporary Western society is heavily influenced by its religious and cultural roots. ${ }^{22}$

Religion cannot be separated from the ability to believe in transcendence, which is the Czech equivalent of religiosity. It is a personally experienced and socially expressed relationship to a reality that is considered to be transcendent. ${ }^{23}$ For contemporary society, especially in Western countries, there is a typical religious pluralism that generates different types of church (institutionalised) religiosity, as well as deinstitutionalised (alternative) religiosity, which has interfaces and a certain overlap with spirituality. ${ }^{24}$ Traditional religiosity is associated with religious institutions, in the European space, in the Czech context, and specifically with the Christian Church. This type of religiosity is characterised by organisation, connection to Church institutions, membership in the Church, participation in Church activities, etc. According to the research conducted by Czech and foreign sociologists of religion (The Detraditionalisation and the Individualisation of Religion 2006, The International Social Research Program ISSP 2008, The European Study of

19 Cf. Jan KAŇÁK, Postoje studentů sociální práce ke spiritualitě a náboženství: výstupy z pilotní studie, in: Sociální práce v nejisté době, eds. Ondřej ŠTĚCH - Peter PATYI - Zuzana TRUHÁŘOVÁ, Hradec Králové: Gaudeamus, 2016, pp. 68-73.

20 Cf. Zdeněk NEŠPOR - Dušan LUŽNÝ, Sociologie náboženství, Praha: Portál, 2007, pp. 15-16.

21 Cf. Zdeněk NEŠPOR - David VÁCLAVÍK a kol., Příručka sociologie náboženství, Praha: SLON, 2008, pp. 122-125.

22 Cf. Zdeněk R. NEŠPOR, Kvalitativní sociologické studium současné české religiozity, in: Jaká víra? Současná česká religiozita/spiritualita v pohledu kvalitativní sociologie náboženství, ed. Zdeněk R. NEŠPOR, Praha: Sociologický ústav AV ČR, 2004, p. 13.

23 Cf. Ivan O. ŠTAMPACH, Na nových stezkách ducha, Praha: Vyšehrad, 2010, p. 16.

24 Cf. Zdeněk NEŠPOR and David VÁCLAVÍK a kol., Př́ručka..., p. 167. 
EVS Values) Czech society is not very interested in an organised, traditional religion based on the Christian tradition. Despite this fact, a strong belief in various phenomena (that are considered to be an alternative religiosity) still persists. However, the low degree of Church religiosity does not mean that there is not a great interest in supernatural and spirituality in Czech society. On the contrary, the relatively strong belief in supernatural and the fact that this supernatural power can influence the facts in human lives penetrates into different spheres of life, where religious and quasi-religious concepts operate. ${ }^{25}$ The spiritual dimension (defined and experienced by any person) can play an important role in the life of an individual. Given the nature of social work as such, there is a part of a professional approach which usually brings a certain degree of personal engagement of the worker (the personality of the worker and personal assumptions I consider an important part of social work). It can be assumed that the spiritual dimension, i.e., spirituality (which is a part of the personality of the social worker) will be (in a certain sense) a part of social work performance. And as such, it can affect (among other factors) burnout syndrome which potentially threatens any helping professional. Spirituality may not always have a positive effect when preventing burnout syndrome (or on the psychological state of a helping worker). Spirituality can take radical, unhealthy forms, and affect man and the process of assisting in a negative way. Burnout syndrome can also go hand in hand with the spiritual crisis of man. For the purposes of this article, I shall adhere to the most general definition. It defines spirituality as a spiritual life, which is perceived strongly individually. ${ }^{26}$ Spirituality (in this article) is therefore understood as the spiritual dimension or spiritual aspect of a person characterised by a personal relationship with the transcendent, or a life sense that does not have to be bound to a particular religion (this could be divided into a religious and non-religious, and secular or alternative spirituality). As one of the dimensions of man, it produces spiritual needs that are to be satisfied to a certain extent and which (if not fulfilled) will start producing signs.

\section{Burnout Syndrome}

\subsection{The term}

Students in the helping professions meet with burnout syndrome theory at high school. Like every concept, burnout syndrome evolves over time and has shifted and expanded considerably from its initial definition, given by Herbert Freudenberger. It originally appeared in psychology and psychotherapy in the 1970s as a well-known phenomenon of the total exhaustion of the body (containing physical, psychological and emotional aspects). ${ }^{27}$ This syndrome affects the entire psychosomatic area in various places, with physical, mental and behavioural symptoms. Boredom, fatigue, resignation, increased irritability, critical attitudes, and other changes take place. ${ }^{28}$ Burnout syndrome and its eventual outbreak and course are controlled and influenced partly by the social environment of man, and partly by his or her personality. Both external and internal factors are involved in the interaction. A worker in the helping professions is a professional whose mission (and in many professions, the workers themselves actually consider their job to be a personal mission) is to help a person

25 Cf. Dana HAMPLOVÁ, Čemu Češi věří: dimenze soudobé české religiozity, Sociologický časopis / Czech Sociological Review 4/2008, pp. 704-705.

26 Cf. Ivan O. ŠTAMPACH, Nahradila spiritualita náboženství?, in: Spiritualita. Fenomén spirituality z pohledu filozofie, religionistiky, teologie, literatury, teorie a dějin umění, pedagogiky, sociologie, antropologie, psychologie a výtvarných umělců. Sborník transdisciplinárních esejů s mezinárodní účastí, eds. Hana STEHLÍKOVÁ BABYRÁDOVÁ - Jiří HAVLÍČ́EK, Brno: Masarykova univerzita, 2006, pp. 99-105. Cf. Jaro KŘIVOHLAVÝ, Hořet, ale nevyhořet, Kostelní Vydří: Karmelitánské nakladatelství, 2012, p. 58.

28 Cf. Martina VENGLÁŘOVÁ et al., Sestry v nouzi: Syndrom vyhoření, mobbing, bossing, Praha: Grada, 2011, p. 24. 
(a client, a patient) in his or her difficult life situation in order to manage, improve or, ideally, solve it. The focus of the helping professions is on a person, an individual human being who has his or her specific needs. The fulfilment of those needs (to a larger or smaller extent) is ensured or helped by the worker. Partially separate or even completely isolated, one's own personality and personal involvement in this area is unthinkable. Motivations, values or personal beliefs and experiences often lead people to choose one of those helping professions for their own. Therefore, there is a high risk of developing burnout syndrome, especially if one is engaged in the job with his or her personality without any limits set, and he or she does not have any effective tools to prevent this threat. When the symptoms of burnout syndrome are manifested, the individual is affected in a physical, mental, social or spiritual dimension, and possibly even in several (or all) simultaneously. This is then reflected in both personal and professional life.

\subsection{The causes of burnout syndrome}

Kopriva states that burnout syndrome can be caused in three different ways. The first is the loss of ideals, the second is workoholism, and the third is a 'terror of opportunity', which is manifested by an inability to set lower limits when accomplishing the job requirements. ${ }^{29}$ There are several causes leading to burnout syndrome. These can be characterised by location, as internal (such as personality, attitudes and habits of an individual), or as external (which includes, in particular, relationships with others, working conditions and the general set-up of society). Rush introduces ten of the most common causes that may (in varying degrees and combination) contribute to the formation of a psychological, emotional and physical condition known as burnout syndrome. It is a feeling of urge rather than a feeling of professional fulfilment, an inability to slow down, an effort to do everything on one's own, an exaggerated attention to strange problems, focusing on details, unrealistic expectations, too much of a routine, an incorrect view of God's priorities in our lives, a bad physical state, and constant rejection from others. ${ }^{30}$

We could find many other possible causes leading to the development of burnout syndrome, some of which would be similar and some perhaps different. Whatever the causes, however, they inevitably lead to feelings of exhaustion, apathy, and a changed attitude towards work that has previously fulfilled the person. In worse cases, it also can lead to severe health complications with a risk of permanently damaged health. All of these findings should lead to an effort to eliminate the risks and to strengthen competencies in the prevention of burnout syndrome.

\subsection{The Prevention of Burnout Syndrome and Spirituality}

Prevention has a very significant impact on burnout syndrome. Prevention is a basic tool for avoiding problems and related context. Social workers often find themselves in situations where they do not pay attention to themselves, their body and to the signals it gives them because they are focused on helping and supporting clients. Nevertheless, helping professionals should not lose awareness of themselves (as they are themselves an important tool for the helping process). A social worker enters into a relationship, a dialogue that is the core of social work. The support of a client and resolution of his or her social situation cannot be carried out properly if the social worker struggles with some obstacles, stressors, and adverse factors that can negatively affect the whole helping relationship.

29 Cf. Karel KOPǨIVA, Lidský vztah jako součást profese, Praha: Portál, 1997, pp. 101-102.

30 Cf. Myron D. RUSH, Syndrom vyhoření, Praha: Návrat domů, 2003, p. 18. 
There is a wide range of tools and techniques to prevent burnout syndrome (concerning the social worker's activity), ranging from the setting of boundaries between professional and personal life, through protecting and maintaining mental health, to specific techniques designed in order to reduce stress and increase individual wellbeing. Spirituality (as one of the factors that affect the mental health of an individual) undoubtedly belongs to the category of protective agents.

This does not have to be the case with all individuals, although it is debatable whether certain contents (which are not considered to be spiritual by people) can indeed be regarded as spiritual. Sociological research shows that Czechs only perceive as religious the activities and ideas that are associated with institutional religion, whereas belief in the supernatural (standing outside of the official Church doctrine) is considered to be 'non-religious - spiritual. ${ }^{31}$ Kubicová talks about spiritual coping strategies (the processes of managing the external and internal factors which the individual is exposed to and which he or she evaluates as burdensome or threatening). These are based on faith in spiritual values. At the heart of these processes is often the question of life objective, the sense of life, and the protective function (which are managed in relation to the existing system of meanings, the control system, and individual well-being). ${ }^{32}$ Spirituality, belief, and religion can help people manage their lives, cope with stress, and face obstacles and pitfalls in their personal and professional lives. Mandinová even mentions the positive influence of faith on human health. ${ }^{33}$ In today's professional and laity discourse, we can meet a holistic approach to man. This view includes four dimensions: biological, psychological (mental), social and spiritual. ${ }^{34}$ It characterises man as a four-dimensional being. Each dimension generates certain needs that should be fulfilled on an individual scale.

\section{The Research Probe - Testing the Understandability of the Questions}

Based on the above mentioned theoretical basics, I conducted a quantitative research probe to prove the existence of a relationship between the two variables - burnout syndrome and spirituality. The aim of the probe was to find out whether social workers and social service workers consider spirituality as a protective factor (that can participate in the prevention of burnout syndrome) and if so, what is the particular form of this spirituality.

A quantitative research probe was conducted through questionnaires distributed amongst social workers and workers who work in organisations providing social services in the South Bohemian region. The respondents had to fulfil two conditions added into the sample - they were to be workers in helping professions and they were to be performing social work. Respondents participated in an accredited training course (the accreditation of the Ministry of Labour and Social Affairs No. 2013/0542-PC / SP / VK) The Combatting of Burnout Syndrome. This course was organised by THEIA - a crisis centre in České Budějovice. The answering of questions in the questionnaire was not mandatory. It was just one of the several activities that were implemented within the course. In one block of this training course, questionnaires were given to participants by the lecturer. In total, 51 respondents participated. Two questionnaires had to be rejected for being incomplete. The total number of valid questionnaires was 49 . The sample of respondents showed a gender standard typical of social work, women were represented by

31 Cf. Dana HAMPLOVÁ - Blanka ŘEHÁKOVÁ, Česká religiozita na počátku 3. tisíciletí, Praha: Sociologický ústav AV ČR, 2009 , p. 62.

32 Cf. Alina KUBICOVÁ, Výzkum copingových strategií mužů a žen na pozadí nábožensko-spirituálních postojů, Psychologie a její kontexty 2/2010, pp. 121-133.

33 Cf. Petra MANDINCOVÁ, Psychosociální aspekty péče o nemocného, Praha: Grada, 2011, p. 63.

34 Cf. Michael MARTINEK et al., Praktická teologie pro sociální pracovníky, Praha: Jabok, 2010, pp. 22-23. 
45 participants (92\%), men were represented by $4(8 \%)$. Data collection was conducted from November 2016 to March 2017.

The questionnaire contained six questions that focused on spirituality as a factor contributing to the prevention of burnout syndrome. If we talk about prevention and the possibilities to minimise the occurrence of burnout syndrome, there should be some space for expressing and reflecting the spiritual dimension in the workplace. This is relevant especially during the performance of social work which (as mentioned above) places emphasis on all the dimensions of man (including the spiritual). Spirituality was, for the purpose of the questionnaire, characterised as a spiritual dimension that contains a certain personal relationship to the transcendent, either being God or a supernatural power. Given that the research probe was conducted with a relatively small number of respondents (although the workers were from different types of organisations involved in social work) and was focused on a narrow section of the problem (specifically formulated, generalised questions), its results cannot be fully generalised. Large-scale quantitative research would ideally need to be carried out. Its results could be then compared with the results of the research probe.

The first question tried to find out whether workers think spirituality is helping or can serve as a prevention of burnout syndrome. This question was formulated very generally and simply for the sake of understanding by the respondents, as its purpose was to find out how much influence they give to spirituality (not to exhaustively define what they mean by spirituality). The answer to this question was specified in a five-step scale - certainly yes (33\%), yes (49\%), no (8\%), certainly not $(2 \%)$ and don't know (8\%). Respondents' answers show that more than two-thirds (82\%) think that spirituality helps or can serve as a prevention of burnout syndrome. It can be concluded from this result that most social workers and social service workers perceive spirituality or the spiritual dimension as part of human unity, or (at least) as a dimension important in the process of maintaining mental well-being and balance (i.e., the psychological essentials possibly threatened by burnout syndrome). It would be very interesting to find out whether the weight of spirituality would be different for a larger number of respondents.

The goal of the second question was to concretise the power of influence that respondents attribute to spirituality in the prevention of burnout syndrome. Respondents (on the six-digit scale 0-5) circled one number according to how strong the protective factor (according to their subjective opinion) spirituality represented ( 0 equals no influence, 5 equals very strong influence). The opinion that spirituality has no effect on the prevention of burnout syndrome ( 0 on the scale of influence) was held by $3 \%$ of the respondents. Also, $3 \%$ of respondents expressed the opinion that spirituality influences burnout syndrome very little (number 1). Then, $16 \%$ of the respondents evaluated the influence of spirituality with number 2 . For $27 \%$ of respondents, spirituality has a medium influence (number 3). A strong influence (number 4 ) was attributed to spirituality by $31 \%$ of respondents and a very strong influence of spirituality (number 5 ) was expressed by $14 \%$ of respondents. These results show that almost half of the respondents consider spirituality to be a strong or even very strong factor in the process of preventing burnout syndrome. On the other hand, spirituality has a minor or medium influence for nearly half of the other respondents. In their opinion, it does not have an essential strength. These respondents may consider spirituality as an additional protective factor which (among other things) interacts with stronger protective factors (i.e., the factors which affect burnout syndrome to a greater extent). Unfortunately, the question did not provide room for identifying any other specific protective factors. For a small number of respondents (about one tenth), spirituality had little or no influence on burnout syndrome. Respondents who answered (the first question) that (in their view) spirituality does not serve as a factor in preventing burnout, either 
circled 0 or 1 on the scale (i.e., they attributed no or little influence to spirituality). Respondents who recognised spirituality and its high or very high influence on the prevention of burnout syndrome and selected scale number 4 or 5 , responded to the first question 'yes' or 'certainly yes.' The midpoint for this question was number 4 (15 respondents).

The third question was formulated as open. It was trying to find out in what way those responding can contribute to the prevention of burnout syndrome. Respondents were supposed to write their subjective view of how spirituality can help, or how it helps them specifically. One third of respondents left this question unanswered. Therefore, such a result cannot be evaluated. There could be several explanations for this. For example, respondents did not want to answer for some reason, did not have such an experience, or it was difficult for them to specify it due to a certain abstraction of the notion of spirituality. Most respondents who did not respond connected spirituality with little influence. Nevertheless, it was interesting that four respondents connected spirituality with a strong influence (number 4 or 5 on the scale), yet left this question blank. Following the first two questions of the questionnaire, it could be assumed that such respondents (who consider spirituality to be important and have a strong influence on preventing burnout syndrome) should bring specific ideas about the forms of this influence. Two-thirds of respondents answered the open question. Their individual statements are grouped into the thematic units of answers in the following table.

Table 1

\section{How specifically can spirituality help you prevent burnout syndrome?}

What is happening makes sense. Everything happens for some reason.

Faith helps overcome difficulties, obstacles.

It provides help, comfort, the feeling that I can handle it all.

It gives the feeling of assurance (that I can ask for help).

It gives a different view of the situation.

It provides an awareness of life and its meaning, belief in something that goes beyond us.

It gives a meaningfulness to work.

Belief or faith in something that goes beyond us.

We have the possibility to talk, listen, confess.

Prayer, Holy Mass, the perception of God's existence.

Thanks to faith, one is stronger, more resistant to stress, burden, negation.

One should not give up in difficult moments.

Have something to rely on.

Follow the principle of love for your neighbour.

It provides comfort, the possibility of confession.

Indicates the worker's steady values.

By meditation.

Chinese Alternative Medicine.

Faith in the good of man, even nowadays.

I don't know. 
The most frequent answers were the statements saying that spirituality gives sense to what is happening and can provide some reason for it. In these expressions one can identify the need for meaning (as defined by V. E. Frankl in his logotherapy and which is also used in social work), a way of how to overcome difficulties and obstacles, it provides help, it calms one down and gives a feeling that one can handle everything and that he or she can ask for help. Spirituality fosters an awareness of the meaning of life and includes faith in something that goes beyond us. The results identify the need for meaning, the need for safety, peace, and a place where it is possible to ask for help. These, I myself identify as important in connection with spirituality. In two responses, specific Christian manifestations of spirituality (prayer, holy Mass, being conscious of God's existence, the principle of love for your neighbours) were identified. In one response, spirituality unrelated to the traditional, historical Church emerged (Chinese Alternative Medicine).

The fourth question was trying to find out whether respondents had experienced burnout syndrome or some of its symptoms, such as depression, indifference, aversion, lack of concentration, reduced willingness to work with people, problems with sleeping, and others. It was a closed question with three categories of answers - yes, I have experienced burnout syndrome (10\% of respondents); yes, I have encountered some manifestations of burnout syndrome (66\% of respondents); no, I have not experienced it (24\% of respondents). These responses show how much social workers and workers in social services are endangered by burnout syndrome. Three quarters of respondents at least met the symptoms that accompany this negative and demanding mental and physical condition that threatens man both personally and professionally. Respondents who responded positively to the experience with burnout syndrome or its symptoms were asked (in open question 4.1) whether their spirituality was involved in solving burnout syndrome (or its manifestations) and, if so, how. However, 56\% respondents left this question unanswered, even though they stated an experience with burnout syndrome (or its symptoms). As with the third question (where one third of the respondents did not mention a specific way of how spirituality can help prevent burnout syndrome), we cannot identify the reason why question 4.1 was left blank. It is not possible to clearly state that those who did not answer the question also had not included a spiritual dimension when solving their situation. It would be possible to assume (to some extent) that they were not aware of the involvement of spirituality, or they considered spirituality to be an intimate dimension of their lives and they did not want to speak about it publicly (even though the questionnaire was anonymous), or that they could not identify the involvement of spirituality. A further $22 \%$ of respondents stated that spirituality was not used or involved. The same number (22\% of the respondents) mentioned an engagement of their spirituality when solving burnout syndrome. These respondents (who gave a positive answer to the question about the involvement of spirituality in solving problems connected with the burnout syndrome) presented specific ways. These are listed in Table 2. 
Table 2

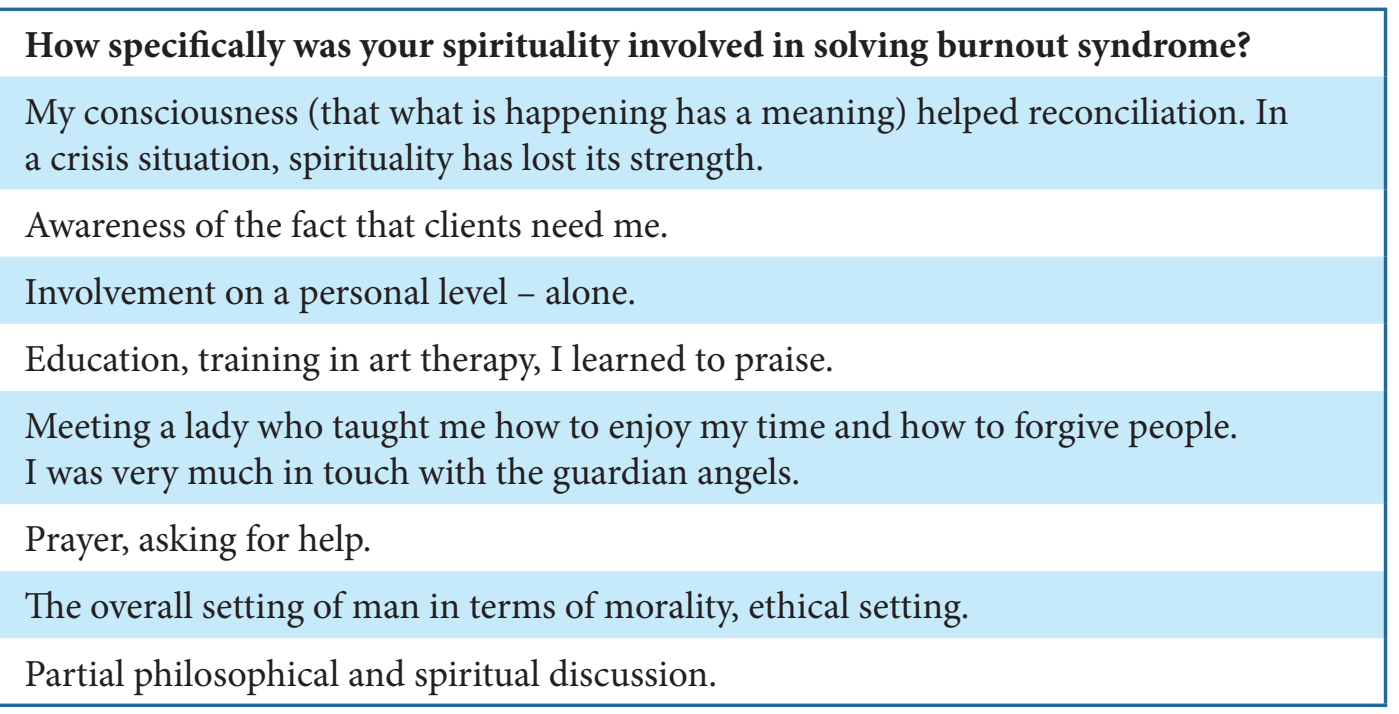

Answers have revealed meanings such as reconciliation, awareness of the fact that clients need him or her, meeting with a person who supported him or her, prayer, a request for help, philosophical and spiritual discussion, and morality, the ethical setting of man. One of the respondents stated that (at the time of the crisis) his or her spirituality lost its strength. It shows that spirituality also can have other influences (than the one which supports human psyche and resilience) and can also have the opposite impact. Given that more than half of respondents did not respond to this question, these answers cannot be generalised or even sorted into thematic units within the sample of respondents.

The last question was semi-open and focused on promoting the involvement of spirituality within the workplace of the respondents. The goal was to find out whether the staff at their workplaces had a place to engage and reflect on spirituality and whether they were interested. I have put this question in line with the above-mentioned assumption that burnout syndrome affects individuals on both the personal and the working level. The aim of the question was to find out if respondents had the opportunity to express their spiritual dimension at the workplace and whether they did or did not express their spirituality. Respondents' answers were expressed on a four-level scale: yes, and I use this (17\%), yes, but I do not use it (20\%), no, but I would use it (9\%), no, and I do not use it $(54 \%)$. When workers used spirituality at their workplace (as one of the factors contributing to the prevention of burnout syndrome) it was mentioned in three responses in a form of supervision. It was not specified whether it was team or individual supervision, or whether spirituality was addressed explicitly or as part of a particular area. In one case, discussions were held (not provided by the organisation) in a narrow circle of colleagues.

An interesting conclusion can be drawn in connection with the last question - although almost half of respondents consider spirituality to be a strong or even very strong protective factor playing a role in the prevention of burnout syndrome, only less than one fifth use the possibilities of involvement and the reflection of spirituality in the workplace, and one fifth of respondents do not use it although there is the option available. More than half of respondents do not use or work with the spiritual dimension in the workplace (or at least do not state it). From these results, we can conclude that there is a weak connection between spirituality (perceived as a personal issue) and the workplace (where social work is performed). In my view, it would be worthwhile to map out this situation in organisations that claim to have Christian foundations. The question would be 
whether in these organisations the interconnection of the personal and professional level would be different than in our current sample of respondents.

\section{Conclusion}

The article aimed to introduce spirituality as one of the factors that help prevent the occurrence of burnout syndrome. Through a quantitative research probe, it focused on the opinions and experiences of social workers and workers in social services with spirituality and its impact on burnout syndrome. It tried to enlighten (generally) the concepts of spirituality, religiosity and religion.

Spirituality as a personally experienced relationship to transcendental reality, and as the spiritual dimension of life that can be understood very individually, considers more than two-thirds of respondents as one of the possible sources that can prevent burnout syndrome. Less than half attributed to spirituality a strong influence and considered it a significant protective factor. Spirituality can specifically help respondents in terms of meaning and meaningfulness of life (events, work), and gives the feeling of consciousness that there is something transcendental, the consciousness that one can manage things, that he or she is not alone and has a place to turn to for help, support and understanding. Answers have revealed both the influence of traditional Christian faith (the consciousness of God's existence, prayer, confession, the command of love for your neighbour), and the influence of alternative religiosity (alternative Chinese medicine).

Although spirituality is important for a number of respondents and (according to them) has a connection with burnout syndrome, it has not always been involved in the solution for it or its symptoms. If it was incorporated, it was either an informal talk in a colleague circle, or a rather unspecified involvement through supervision. The identification of spirituality as a factor contributing to the prevention of burnout syndrome (which the workers themselves considered to be significant) could create the possibility for special setting care for social workers and workers in social services, i.e., enriching it with a spiritual dimension. It would be interesting to extend the research probe and add quantitative research to it. A questionnaire could be distributed amongst a larger number of social workers and workers in social services so that generalisable conclusions could be drawn. 


\section{Spirituality as a Source for the Prevention of Burnout Syndrome}

\section{Abstract}

The article deals with spirituality as one of the factors contributing to the prevention of burnout syndrome. It uses the concept of man as a four-dimensional being including a spiritual dimension as well. Part of the article is also a research probe among social workers and workers in social services. It discovers their views on spirituality (their possible experience with it, and its influence on burnout syndrome).

Key Words: spirituality, religiosity, burnout syndrome, social worker, worker in social services

\section{Author contact}

\section{Nicole Emrová MA}

University of South Bohemia in České Budějovice

Faculty of Theology, Department of Ethics, Psychology and Charity Work

Kněžská 8, 37001 České Budějovice

zvonin00@tf.jcu.cz 